\title{
Dictynna
}

Dictynna

Revue de poétique latine

$6 \mid 2009$

Varia

\section{The Poetics of Alliance in Vergil's Aeneid}

Bill Gladhill

\section{(2) OpenEdition}

\section{Journals}

Electronic version

URL: http://journals.openedition.org/dictynna/260

DOI: 10.4000/dictynna.260

ISSN: 1765-3142

\section{Electronic reference}

Bill Gladhill, «The Poetics of Alliance in Vergil's Aeneid », Dictynna [Online], 6 | 2009, Online since 26 November 2010, connection on 10 September 2020. URL : http://journals.openedition.org/dictynna/ 260 ; DOI : https://doi.org/10.4000/dictynna.260

This text was automatically generated on 10 September 2020 .

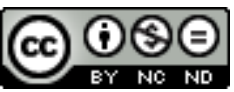

Les contenus des la revue Dictynna sont mis à disposition selon les termes de la Licence Creative Commons Attribution - Pas d'Utilisation Commerciale - Pas de Modification 4.0 International. 


\title{
The Poetics of Alliance in Vergil's Aeneid
}

\author{
Bill Gladhill
}

1 The following paper argues that the series of desecrated altars in the Aeneid reflects prior moments of ruptured alliances that have taken place in the epic cycle and Roman history more generally. Vergil has constructed these ruptured alliances along of number of parallel lines that focus on the various means by which the poem constructs ethnic and spatial unification. From the perspective of ethnic amalgamation the infectum foedus of Aeneid 12 raises a number of problems concerning the foundation of Rome and the nature of Roman alliance through time. This problematic alliance that ends the poem, however, moves against the theme of East-West unification in which a central feature of Aeneas' actions is the reunification of Europe, Asia and Africa through a new system of alliance.

Gian Biagio Conte famously wrote that the Aeneid is something like a "broken mirror", a "fragmented reality." ${ }^{1}$ The manifold perspectives offered by the narrator and the incredible violence of the poem move simultaneously with and against the poem's imperial cadences, its political metaphors and variegated meanings of its narrative. The poem says one thing, yet tells another and another and another... Since Conte's important formulation, scholars have been making considerable progress in rationalizing the poetics of a fractured narrative. Essentially, one can never contemplate in toto the complex interplay between narrative dilation and closure that organizes much of the poem's tension, while also interpreting the infinitely (sine fine) expanding temporal and spatial spheres of a myth that paradoxically is charging continually with ever more energy, more directly and intently, toward a final battle between two men in a confined, closed space. ${ }^{2}$ But it no longer seems fruitful to study these elements of the poem as signs of broken, fractured shards of competing meanings that bend the mind into antithetical interpretations (often framed by the tired juxtaposition Augustan and anti-Augustan), but instead to see that Vergilian poetics construct a complex system of spaces where the ontology of Rome is constantly shifting between various times, places, and ethnicities, as though the reader is bearing witness 
not to a fractured poetics of empire, but to a sensitive portrait of the imperial landscape that composed Rome and Roman history. ${ }^{3}$

In the following paper I would like to approach the process of ethnic and spatial unification through what I am calling a poetics of alliance. The poetics of alliance argues that the narrative action of the Aeneid is a function of foedera, or ritual events that perform treaties. ${ }^{4}$ The ways one can approach the poetics of alliance are many and manifold, but for my purposes I will move through arae whose negatively charged valence signifies a crisis of alliance in Vergil's epic landscape, while raising a series of questions about the efficacy and problems connected to alliances. The paper comes in three movements. In the first movement I will discuss the Arae at Aeneid 1.108 and their connection to the violated arae of Aeneid 12. After an analysis of these polysemously configured altars, it will become clear that altars are closely connected to the ritual event of a foedus. In the second movement, I will elaborate on the relationship between altars and foedera throughout the epic in order to suggest that the altars signify that the epic landscape of the Aeneid is a function of a series of violated foedera that have resulted in the sundering of Europe and Asia. Violations of arae reflect the aftermath of prior violations of alliance; one cannot be separated from the other. In the final movement, I will broaden the argument beyond the scope of violated altars in order to address a primary concern of the Aeneid, the re-fusion of Europe and Asia through Trojan colonization and alliance. While the narrative moves through a series of violent acts upon altars that reflect ruptured alliances in the mythic past, the epic landscape itself is becoming reunited and redrawn according to an entirely new poetics of alliance. Much of my analysis will follow insights first offered by Servius. ${ }^{5}$

\section{Altar Violation, Alliance, and the Foundation of Rome}

4 Early in the poem the Aeneid makes no secret that altars are troubling spaces in the poetic landscape, as suggested by the cluster of rocks called the Arae by the Itali, where Orontes is thrown from his ship during the storm of Aeolus. The first encounter with Arae is contemporaneous with the first death (and sacrifice) of the Aeneid. ${ }^{6}$ While his death and its relation to altars spread branch-like throughout the rest of the poem, causing no shortage of literary analyses, I wish to follow a branch similar to that taken by Servius. Servius is keenly aware that the Arae play a dynamic role within the narrative as markers of memorial of the fines imperii separating Carthaginian and Roman spheres of influence. In a note to Aeneid 1.108 Servius states the following in reference to the line, saxa vocant Itali mediis quae in fluctibus Aras : ${ }^{7}$

haec autem saxa inter Africam, Siciliam, et Sardiniam et Italiam, quae saxa ob hoc Itali aras vocant, quod ibi Afri et Romani foedus inierunt et fines imperii sui illic esse voluerunt. unde et Dido

litora litoribus contraria, fluctibus undas imprecor. ${ }^{8}$

(ad Aen.1.108)

5 Servius continues the discussion, offering other appellations for the Arae found in the works of Sisenna, Claudius Quadrigarius, Varro, and some unnamed Greek (among other unnamed) sources. Servius' comments show the ease with which Vergil moves from fabula to historia, that is from a divinely caused storm to space within the epic topography that is a function of historical action. ${ }^{9}$ The Arae establish the boundaries of imperium between Carthage and Rome prior to the first Punic War. ${ }^{10}$ The shipwreck 
beside the Arae is a moment of historical prolepsis within the mythic past ; the Trojans are wandering into a landscape that is already imbued with the memory of the future. This linkage between the Arae and a foedus, at first glance, seems like a bit of antiquarian information slipping into Servius' commentary that has no bearing on textual analysis. ${ }^{11}$ Yet, the range of sources cited lends this comment a particularly forceful valence of scholarly authority, and Servius' gesture to Dido's curse belies a rather inspired insight, one that would be fruitful to continue, especially when considering Pamela Bleisch's thesis that arae are etymological allusions to Greek arai, curses, a feature of language inherent to foedera. ${ }^{12}$ Vergil even seems to suggest this reading by attaching the epithet fidus to Orontes (1.113); not only is Orontes the first hero of the poem to die, but he is also the first to receive an epithet that is both etymologically connected to foedus (and fides) as well as part of the cognitive system Romans used to rationalize human sacrifice. ${ }^{13}$

6 Servius' comment catalyzes the reader to look outside of the text, to situate the epic landscape within topographical and political referents, and to compare it to similar moments when fabula and historia merge around altars. Servius' insight on the Arae is far cleverer than he may have realized ; they refer not only to Dido's curse, but they are an important configuration for an interpretation of the foedus between Aeneas and Latinus in Book 12. Emphatically, the Aeneid is framed by ring (or altar ?) composition whereby the vast action of the poemhappens between two arae, and significantly these arae are functions of the ritual event of a foedus. Leaving behind for the moment the deep connection between these two altars, I would like to use Servius again as a frame in which to set the foedus of Aeneid 12 in order to illustrate how Vergil configures the arae in a way that upsets the reader's traditional approach to this episode. Servius states the following at Aeneid 12.116 (campum ad certamen magnae sub moenibus urbis): Totus hic de foederibus locus de Homero translatus est, ubi Alexander Paris cum Menelao singulari est certamine dimicaturus (ad Aen. 12.116). ${ }^{14}$ Servius tells us that the foedus between Latinus and Aeneas is "completely translated" from Iliad $3 .{ }^{15} \mathrm{He}$ spells out the narrative parallels ad Aen. 12.176:

sane iuxta Homericum foedus hic inducit fieri : nam ut ibi Priamus,

ita sic Latinus ; ut hic Aeneas, ita ibi Agamemnon. et priores precantur qui servaturi sunt foedus, quod ruperunt qui posteriores iuraturi erant, ibi per Pandarum Troiani, hic Tolumnium Latini. ${ }^{16}$

(ad Aen 12.176)

7 Although Servius captures succinctly the overt parallels between each episode, his focus on general patterns of imitation create a number of problems. If Aeneas is comparable to Agamemnon, what does this say about Aeneas, and likewise, how does Aeneas force us to reread Homer's Agamemnon? Why would Vergil create an episode that intrinsically recalls Trojan perfidy in the Iliad through the overt impiety of the Italians? This binary categorization Servius encourages masks very significant differences between Aeneid 12 and Iliad 3 that are far more important than surface parallels. To point to one example, Servius compares Tolumnius and Pandarus, which appears to be a clear parallel. Yet, Vergil himself describes Pandarus at Aeneid 5.496-7 as Pandare, qui quondam iussus confundere foedus in medios telum torsisti primus Achivos. Confundere foedus is significant: this phrase is not used to describe Tolumnius, as we might surmise based upon Servius' statement, but rather to the Italian Messapus called avidus confundere foedus in the context of altar desecration and human sacrifice upon altars in Aeneid 12. Later Tolumnius is described as primus in adversos telum qui torserat 
hostis (12.461), a phrase which at one moment gestures to Vergil's Pandarus, and at another instant severs his action as a violation of ritual since he casts his spear against adversi hostes, a phrase which characterizes the Trojans, Arcadians and Etruscans as hostile enemies, not ritual observers. It is Messapus to whom Vergil links Pandarus' ritual violation, a point we will flesh out below. ${ }^{17}$

8 Although Servius' approach lacks the requisite sophistication to elucidate the foedus of Aeneid 12, the clear "translation" by Vergil of Iliad 3 is nonetheless an important statement. The ritual activity of both episodes overlaps slightly; the two leaders of their respective peoples perform the ritual, which involves the invocation of divine witnesses to the oaths, the declaration of terms, and the sacrifice of animals. ${ }^{18}$ But it is in the key divergences between the Homericum foedus and the Vergilian foedus where the Iliadic parallel becomes especially pronounced and vital. The Iliadic of pkid in Book 3 implicate the Trojans fully in the violation of the compact, resulting in the eventual fulfillment of the oath-curse pronounced by both armies and most dramatically confirmed in the brutal death of Astyanax and the allocation of the Trojan Women to

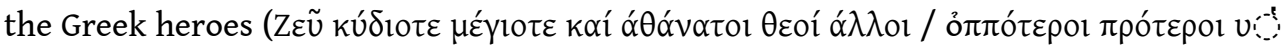

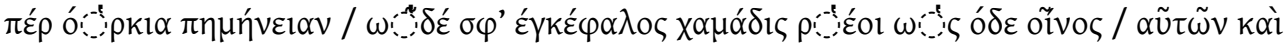

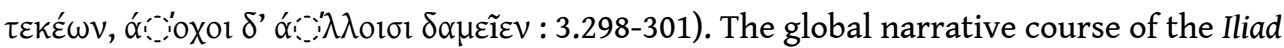
is the performance of this curse, which is finally brought to conclusion upon the destruction of Troy. ${ }^{19}$ This horkos will not end the war, and the ritual violation of the Trojans stands like a shadow behind the epic action of the next twenty-one books. The audience knows that Troy will fall a few months after this oath. The force of the dilation centers on those moments of the epic when heroes become signifiers of Troy itself, so that one simultaneously experiences the death of an individual as well as the annihilation of a community. The Aeneid, on the other hand, places the foedus in the final act as a marker of closure to the epic as a whole. This is an obvious distinction, narrative dilation versus narrative closure. The problem, which we shall discuss below, is that the foedus of Book 12 only appears to be a formal closure ; in fact, its dilatory effect is far more dramatic and profound than that of the Iliad. ${ }^{20}$ The parallel with the Iliad, however, prepares us for this facet of the poem's conclusion that it will end with the expectation of narrative dilation and the interpretative cruces that accompany it. ${ }^{21}$ The Aeneid ends with a destabilizing dilation, since the enactment of the foedus in the death of Turnus leaves open questions about the efficacy and consequences of this "alliance."

9 Be that as it may, for our purposes the single most significant difference between the two poems is ironically found at the moment of their most obvious similarity. In both epics the foedera are broken, and since Servius, Tolumnius' spear cast has been interpreted as the act that ruptures the foedus, in large part because of the Homeric model. The Homericum foedus is officially ruptured when Menelaos is struck by Pandarus' arrow, an event that Vergil curiously connects to the blush of Lavinia. ${ }^{22}$ Unlike the recipient of Pandarus' arrow, who actually participated in the contest authorized by the ritual, the recipient of the hasta is an unnamed individual wearing a balteus, the most beautiful of nine brothers, all of whom stand on the periphery of the ritual watching Latinus, Aeneas, and Turnus perform the foedera (Aen. 12.257-76). That his death appears to gesture to Pallas and not Menelaos is clear. The hasta volans in the Vergilian foedus violates neither the ritual space, nor the oath, nor the agents of the ritual. Unlike in the Iliad where both armies pronounce the oath, no one else outside of 
Aeneas and Latinus states an oath, which suggests that the bystanders may not be bound to the ritual events occurring. ${ }^{23}$ In this respect, the death of the brother is collateral and arbitrary, a tragic event, but it in no way violates the foedus. Pandarus actually violates his oath and strikes the victor of the sanctioned battle, while Tolumnius violates no oath and strikes none of the participants of the ritual. It is notable in this regard that Pandarus' arrow is thrown against medii Achivi, in contrast to Tolumnius' adversi hostes; the shift from medii to adversi signifies the different ritual circumstances of the witnesses within the two poems, between those who are bound by an oath, thereby losing their inimical valence, and those who pronounce no oaths, and therefore are still enemies at war.

Vergil's purpose in driving a wedge between Tolumnius and Pandarus, between Aeneid 12 and Iliad 3, is to confuse exactly which party or individual is responsible for violating the foedus. The Iliadic episode is devoid of arae. ${ }^{24}$ Vergil builds the arae of Book 12 in order to have them desecrated and destroyed. The ritual of Aeneid 12 is infected by the defilement of the arae dis communibus built in preparation to the foedus (12.118), and his description of their violation looks back directly to the Arae of Aeneid 1. Essentially, at one of the most Iliadic moments of the Aeneid, Vergil severs his epic from its primary model and accords it with the themes and structures operative within his own poem. Their destruction is described in this way:

...quos agmina contra

procurrunt Laurentum, hinc densi rursus inundant

Troes Agyllinique et pictis Arcades armis :

sic omnis amor unus habet decernere ferro.

diripuere aras, it toto turbida caelo

tempestas telorum ac ferreus ingruit imber,

craterasque focosque ferunt. fugit ipse Latinus

pulsatos referens infecto foedere divos. ${ }^{25}$

(12.279-86)

11 The altars are ripped apart by all the parties affected by the performance of the foedus Italians, Trojans, Greeks and Etruscans - but the ethnicities become elementalized as they "inundate" (inundant) the rushing Italians, as though their flesh, bone, and armor burst into torrents of water. The populations flood into the arae between them. The storm imagery continues; immediately after the destruction of the altars a tempest of spears (turbida...tempestas) rains down (imber) on the warriors. The connection between foedus, arae and storms - and we should include the narrative parallels of Juno-Aeolus and Juno-Juturna in the creation of these storms - situate the activity in Book 12 in relation to the shipwreck beside the Arae in Book 1 and all the cosmologically cataclysmic imagery and symbolism connected to it. ${ }^{26}$

While the language of altar desecration suggests the potentiality of cosmic annihilation as the parallel to the Arae indicates, the purpose of the arae themselves in the context of the foedus is the qualitative realignment of Iliad 3 away from an individual's responsibility for the rupturing of the foedus to collective pollution. This is best evidenced at the moment of the altar's desecration; after Tolumnius strikes the brother, his eight siblings rush against the altars, matched in their onslaught by the Italians, Trojans, Arcadians, and Etruscans, all of whom are implicated in the syncopated perfect diripuere aras, with aras replacing ere/erunt through elision (diripueraras). The syncopation and elision result in the formation of a word whose syntactic distinctions between the parts of speech break down, as objects replace the 
verb's marker of person and number, while the verb itself is elided to become an accusative plural. This mixture of syntactic elements is an iconicity for the events unfolding in the narrative. This point is particularly relevant in light of the Iliadic model; in the Iliad all of the soldiers pronounce the same oath, and the hairs of the sacrificial animals are passed out to each man. ${ }^{27}$ It is only in the violation of the altars do the spectators of the ritual in the Aeneid actually touch and participate in the event in a way that is reminiscent of the horkos of the Iliad.

13 As the populations inundate the altars, Vergil then focuses on key characters whose desecration of the arae greatly ambiguates the sacrilegious and the pious while revealing perplexing possibilities about the ritual efficacy of this foedus. Is the destruction of the arae and the "sacrifice" upon them the ritual performance first begun by Aeneas and Latinus? On the one hand, Messapus, whose connection to Pandarus has already been noted in the phase avidus confundere foedus, "smites" (ferit) the Etruscan Aulestes upon the arae..$^{28}$ This would suggest that Messapus is the prime mover of the violated foedus. Aulestes, on the other hand, had already fallen upon the arae themselves, which is in and of itself an act of desecration, requiring further sacrifice (piaculum). ${ }^{29}$ This further sacrifice happens to be Aulestes himself : hoc habet, haec melior magnis data victima divis (12.296). That Aulestes is an inverted piaculum highlights the theme of ritual perversion, but it also suggests that it is the collective violation of the arae themselves by all the ethnicities that marks the ritual pollution of the foedus, not any single act of any single character. To put it another way, is it Messapus' desire (avidus) to rupture the foedus that becomes the ultimate catalyst for its infection or the act of altar violation by Aulestes as his body tumbles into the sacred space? The text offers no clear answer to this question. The rhythm of violation continues as the Itali "despoil" the calentia membra upon the arae (which may refer to the limbs of Aulestes : 12.297). Coryaenus, a Trojan, tears a flaming log from the altar and shoves it down Ebysus' throat and then smites (ferit) his latus (12.298-9). The two uses of ferit, one in reference to an Italian, the other to a Trojan, suggest that this foedus has been struck, a foedus that is infected (infectum foedus : 12.286).

Infectum is itself a gloss on the "folk" etymology connecting foedus to foed-itas (see for example Catullus 64.223-4: canitiem terra atque infuso pulvere foedans,/ inde infecta vago suspendam lintea malo/"befouling my white hair with dirt and dust mixed in, from there I will hang a bleak sail upon a swaying mast"). ${ }^{30}$ Foedus infectum is highly significant ; as Aeneas and Latinus are pronouncing their prayers and oaths over the arae, Vergil gestures to the Itali and their dicta, as their words move from hoping and wishing to actual prayer : qui sibi iam requiem pugnae rebusque salutem/ sperabant, nunc arma volunt foedusque precantur/ infectum/"they (Latins) who just before had hoped for a rest from war and for security, are changed; they now want weapons, pray the pact can be polluted" (12.241-3). While dicta are being spoken over the arae by Aeneas and Latinus, the Itali are praying contra-dicta, as though their own prayers have fused with the ritual actions of Aeneas and Latinus; the ritual events on the periphery of the sacred space run counter to those at the core.

The implication of the desecration of the altars is that the Latins, the various races of Italy and the Trojans are all implicated in violating the ritual of the foedus. ${ }^{31} \mathrm{~A}$ proof of this argument is best seen in an evaluation of Aeneas' oath. Aeneas conditions his oath on the outcome of his certamen with Turnus in the following way: 
cesserit Ausonio si fors victoria Turno,

convenit Evandri victos discedere ad urbem,

cedet Iulus agris, nec post arma ulla rebelles

Aeneadae referent ferrove haec regna lacessant.

sin adnuerit nobis victoria Martem

(ut potius reor et potius di numine firment),

non ego nec Teucris Italos parere iubebo

nec mihi regna peto : paribus se legibus ambae

invictae gentes aeterna in foedera mittant. ${ }^{32}$

(12.183-91)

16 Aeneas states that he is not seeking a kingdom for himself, but rather that both races rule unconquered under eternal foedera and equal leges. ${ }^{33}$ Does this oath come to pass? Do the Teucrians and Italians join in eternal foedera and equal laws? Vergil's language is as close as one can come to stating terms of citizenship, but these terms not fully extended to non-Romans until the conclusion of the Social Wars when "all Italians were Romans," essentially negating the need for foedera. ${ }^{34}$ Aeneas' oath lacks the quality of time needed to shape such a variegated ethnic alliance into a cohesive unit "unconquered under the laws."

17 The negative potential of the oath, however, is also fulfilled. It is the case that the Trojan line does reside in the city of Evander and that the city of Iulus, Alba Longa, will yield its lands, but only after Mettius Fufetius violates foedera with Rome and Alba Longa is sacked. That both potentialities of the oath are realized at some point in the course of Roman history requires explanation : the infectum foedus, which is performed once Aeneas sacrifices Turnus, results in the fulfillment of both the negative and positive conditions of the oath. ${ }^{35}$ This suggests not only that the Trojans are agents in the violation of this foedus, but also that the consequences for its violationare not instantaneous, but are actualized through the course of time. The seed that will grow into Roman Italy is infected. We are not dealing with allegory, but rather Vergil has shown that the links of history are in the process of becoming a chain of events with one link ultimately shaping the course and shape of the links that follow. It is one of the great ironies of the poem that when Juno agrees to terms with Jupiter in Book 12, she has successfully brought to fruition not only the war with Carthage because of the violation of foedera in Book 4, but furthermore the sack of Alba Longa, the Social Wars and Civil Wars because of the foedus infectum. ${ }^{36}$ In fact, Civil War is a violation of these ur-Roman foedera, the consequences of which are profound.

The two key differences in the Vergilian foedus when read in light of the Homericum foedus are whom the hasta strikes and who desecrates the arae. Vergil has displaced the wounding as the marker of violation and joined it to the arae themselves. This point is brought into more vivid focus at 12.311-23 where pius (12.311) Aeneas, unarmed and nudato capite, attempts to restrain the tempest - like Neptune in Book 1 - calling upon the ictum iam foedus et omnes compositae leges. He states that he will make the foedera firma in hand to hand combat (ego foedera faxo/ firma manu). Aeneas is not Neptune, but Menelaos; a sagitta strikes Aeneas recalling the actions of Pandarus. In the Homeric model, one man is able to violate the horkos thereby incriminating his countrymen; in the Aeneid, only a single man abstains from the desecration of the altars, while every other individual violates the foedus. Whereas the striking of Menelaos represents the violation of the oaths, Aeneas' wounding results in the hero's becoming the only character who does not violate the arae foederum by participating in the conflict. It is significant that the poet cannot name the archer from whose bow the arrow originated. 
The archer could have been Italian, Trojan, Etruscan or Arcadian ${ }^{37}$ In the end, it matters naught ; everyone has already been implicated in the infectum foedus.

\section{Altars, Alliances, and the Sundering of East and West}

That the Aeneid is bookended by two arae, which are in one way or another connected to the ritual of a foedus, is cause of enough to explore the activity around the remaining arae of the poem in order to consider whether they are conditioned on the poetics of alliance. A quick tour of violated arae in the Aeneid will provide a pattern that highlights the connection between foedera and arae within the overall design of the poem, which will allow us with greater clarity to understand the full significance in concluding the Aeneid with this troubling foedus. Juno refers to the absence of honor set upon her arae by a suppliant, which suggests a profound breakdown in the relationship between gods and humans (1.48-9). Sychaeus is slaughtered before altars by his brother-in-law (1.348-52). ${ }^{38}$ Sinon refers to arae which are to be used for his own sacrifice in an episode Servius connects to foedus (2.128-9), ${ }^{39}$ Laocoon is compared to a bull slaughtered as it flees from an ara (2.223-4), ${ }^{40}$ Coroebus and the rest of the Trojans in Greek armor are killed before the altar of Athena (2.424-30), ${ }^{41}$ Priam is struck down by Neoptolemus beside altars (2.499-502), ${ }^{42}$ Aeneas violates the tomb of Polydorus while building an ara (3.24-6), ${ }^{43}$ he burns altars while celebrating the Actian games (3.278-80 : ${ }^{44}$ a memorial of closure of a Civil War, a war which Tacitus construes as a violation of foedera), ${ }^{45}$ Andromache sacrifices at twin arae, symbols for Hector and Astyanax (3.305), ${ }^{46}$ and Orestes kills Pyrrhus at his ancestral arae (3.330-2). ${ }^{47}$ Furthermore, Dido's pyre is surrounded by arae in the context of violated foedera $(4.509,520),{ }^{48}$ the votive arae in memory of Anchises through which the anguis slithers in Book 5 is contrasted with the arae destroyed by the Trojan women at the end of the book (5.84-9; 5.659-61), ${ }^{49}$ Romulus and Titus Tatius on the shield of Aeneas stand beside arae as they perform a foedus, ${ }^{50}$ a scene followed immediately by the dismemberment of Fufetius (8.639-41), arae are etched in the shield at 8.718-19 in the context of Augustus' triumphs (...omnibus arae/ante aras terram...), and lastly the arae in Book 12 are violated after an absence of arae for three books, and at a critical juncture in the book Aeneas significantly invokes these arae in their connection to the ruptured foedus : multa Iovem et laesi testatus foederis aras/"having often pleaded with Jove and the altars of the shattered treaty" (12.496). ${ }^{51}$

The entire Mediterranean world and its epic landscape are marred by violated arae, except for Italia, where the first ara to suffer ritual pollution occurs in Book 12. The three sets of arae of Book 8 (Ara Maxima, arae Tatii et Romuli, arae Augusti) are anomalous in this sequence; they are all located in Italy, but they stand outside of the narrative present of the poem, one as a monument signifying victory over a culture monster in the mythic past, and the other two referring to future events in Roman history, one clearly legendary and the other historical. The narrative of Book 8 presents three arae that are marked for their productive and inviolate states. They all memorialize a productive shift in reality while simultaneously bringing Civil War (whether allegorical or actual) to an end. ${ }^{52}$

21 In order to contextualize the various acts of altar desecration throughout the poem, I would like to discuss two violations of foedera within the epic cycle that reveal the underlying causes of Vergil's troublesome epic topography. The first I will discuss 
occurs after the Homericumfoedus in the death of Achilles, and the other begins the epic cycle itself with the rape of Helen. Servius ad Aen 3.321 states the following:

quam (Polyxena) cum Troiani fraude promisissent, Paris post Thymbraei Apollinis simulacrum latuit et venientem Achillem ad foedus missa vulneravit sagitta. tum Achilles moriens petiit, ut evicta Troia ad eius sepulcrum Polyxena immolaretur: quod Pyrrhus implevit. ${ }^{53}$

(ad Aen 3.321)

In this passage Servius refers to one variation of Achilles' death.$^{54}$ In this version of events Polyxena accompanies Priam to the hut of Achilles in order to retrieve the body of Hector. Priam offers Polyxena to Achilles in marriage, but the hero rejects the proposal. After the death of Memnon, Priam offers Polyxena to Achilles a second time on the condition that he ends the war. Achilles meets Priam at the precinct of Thymbraean Apollo in order to discuss the proposal, but is assassinated by Paris as he approaches Priam and Polyxena. Dying, Achilles commands that Polyxena be sacrificed at his grave, an act subsequently performed by Pyrrhus. In one variant Achilles dies upon an altar..$^{55}$ The key detail shared by most sources for this variation is that Achilles is killed when meeting Priam to discuss a marriage proposal that will end the war.

Servius states that this narrative sequence is a foedus. It is important to realize that Servius is reading the events of the epic cycle as a function of foedera and of their violation, which in this case is the murder of Achilles and the sacrifice of Polyxena, an act that marries violated foedera, arae (and Bleisch's arai), and human sacrifice (Dido and Turnus should be on our minds). One might even say that Servius is reading the events of the Aeneid back into the epic cycle, and essentially the narrative of the Aeneid becomes the literary matrix in which Servius sets his own readings of Homer et al. While the death of Achilles blends the myriad of themes we have been discussing (and adding a few more) it is notable that Achilles is slaughtered as he attempts to strike a foedus and that this foedus, which would bring an end to the Trojan War, is completely devoid of any notion of ethnic assimilation and merging, just as was the case with respect to the horkos of Iliad 3.

The second example occurs at Aeneid 10.90-1, where Vergil suggests through the mouth of Juno that the events of the epic cycle ultimately derive from the violation of foedera: quae causa fuit consurgere in arma/ Europamque Asiamque et foedera solvere furto? Servius' comments for these lines are particularly interesting since they indicate that the entire narrative of the epic cycle is motivated by violated foedera. It is important to quote Servius in full :

FOEDERA SOLVERE FVRTO legitur in historiis quod Troiani cum Graecis foedus habuerunt. tunc etiam Paris est susceptus hospitio et sic commisit adulterium. ergo 'foedera solvere furto' amicitias adulterio dissipare : nam furtum est adulterium, unde est "et dulcia furta". et eversi Ilii haec est vera causa : nam foedera quae inter Graecos et Troianos fuerunt, ita soluta sunt. Hercules cum expugnato Ilio filiam Laomedontis Hesionam, Priami sororem, Telamoni dedisset, profecti sunt legati cum Priamo et eam minime repetere potuerunt, illis dicentibus se eam habere iure bellorum. unde commotus Priamus misit Paridem cum exercitu, ut aliquid tale abduceret, aut uxorem regis, aut filiam. qui expugnata Sparta Helenam rapuit. hinc ergo Vergilius utrumque tangit, et istam historiam quam modo diximus, et propter iudicium Paridis : quamvis fabula sit illa res et a poetis composita. ${ }^{56}$

(ad Aen. 10.90)

Servius tells us that the historiae (meaning rationalizing readings, purged of fabulous epic events) judged the rape of Helen as a violation of foedera that existed between the 
Greeks and Trojans. ${ }^{57}$ There are two approaches to the foedera. The first is that Paris committed an act of adultery while under the protection of hospitium, and that this act violated the foedera. Here, a violation of the foedushospitii results in the violation of the political foedera between nations. The other explanation is that Paris invaded Greece and took Helen at the behest of Priam because the Trojan king was unable to reclaim his sister Hesiona, who had been seized by Hercules and given to Telamon. Servius tells us that Vergil alludes to both, in what is perhaps the first "have your cake and eat it too" argument in literary criticism. From the examples given above, we can map the sequence of violated foedera as the following: the rapes of Hesiona and Helen rupture the foedera between Europe and Asia, which give rise to war, and during this war foedera continue to be ruptured between men alone, first in Iliad 3 and then in at least one variant of the death of Achilles.

Can the negative valence of altars in Aeneid 2 and 3 be interpreted as signifiers that foedera have been violated, thereby aligning the narrated past of the poem with events as they unfold in Carthage and Italy? In other words, are the Arae of Book 1 and the arae of Book 12 merely marked places where violated foedera and desecrated altars become unified? I think that it is probable that the massive violation of arae in the Aeneid signifies the continued theme of ruptured foedera, which began with the rapes of Hesiona and Helen that infected the alliance between Europe and Asia. ${ }^{58}$ It is precisely this idea that accounts for the language describing the death of Priam at Aenied 2.501-2: uidi Hecubam centumque nurus Priamumque per aras/ sanguine foedantem quos ipse sacrauerat ignis/"I saw Hecuba together with her hundred daughters, and among the altars I could see King Priam, polluting with his blood the fires he himself had hallowed." ${ }^{59}$ The cognitive association between foedus and foeditas suggests that Pyrrhus' sacrifice of Priam is the fulfillment of the sort of foedera one encounters in the epic cycle - foedera besmirched and foul in their performance upon violated altars. ${ }^{60}$ Essentially, the characters of the Aeneid are in a nightmare world where the chain reaction of violated foedera ripple throughout the epic landscape Vergil inherits, which he fashions for his own poetic, political and symbolic aims, as the historically polysemous language used of the location of Priam's corpse suggests. ${ }^{61}$ It is notable in this regard that the altar of his sacrifice is described as ingens ara iuxtaque veterrima laurus/ incumbens arae: 2.512-13; ingens ara and its veterrima laurus are markers of Magnus. The reference to Civil War in Priam's death suggests that this cycle has continued unbroken from Greek mythology, through Roman legendary history, until the recent events of Vergil's Rome.

Let us return to Aeneid 10.90-1 and the implications of ruptured compacts within an East-West opposition : quae causa fuit consurgere in arma/ Europamque Asiamque et foedera solvere furto/"was it not he who caused both Europe and Asia to rise in arms, whose treachery first violated ties of peace." The rape of Helen results in ruptured foedera that up until that point had created an alliance between the two continents. Organizing the spatial matrices of the poem is the highly charged binary of East and West antagonism (or rather "consurgence"), which Juno characterizes in an almost Herodotean manner, if we agree that furto refers to the rape of Helen. Yet Juno's perception of epic events does not respond to the fact that the effeminate, eastern potentate Aeneas is migrating to the West, a process that restructures this problematic spatial bifurcation and realigns the symbolic content created by it. 
The Polydorus episode is thematically important in this regard because it marks Aeneas' first engagement with Europe after crossing the Hellespont, where he encounters a strange portent while building, of all things, an altar. After founding a city and sacrificing a taurus to Jupiter - an act Servius states was contra morem (ad Aen. $12.119^{62}$ ) - Aeneas attempts to build an ara, an act that (unsurprisingly after the narrative of Book 2 and the presence of iuxta with cornea virgulta and myrtus upon the tumulus suggesting an inversion of Priam's altar) becomes a monstrum as blood and gore seep from the mound. ${ }^{63}$ In his first engagement with Europe Aeneas unwittingly violates arae in the sense that the materials he is using to construct it are polluted by human crime and blood. ${ }^{64}$ The landscape retains the memory of the violated rites of hospitium and the rupturing of all that is fas because of Polydorus' murder by Lycurgus (3.55-61). I would like to suggest that this peculiar episode marks the reenactment of the ruptured foedera between Asia and Europe, which, as Servius told us, was based on the violation of hospitium through adultery. ${ }^{65}$ The death of Polydorus in the context of hospitium, the violation of altars, and the shift from Asia to Europe all suggest that this groaning and gore-filled tumulus in the poetic landscape of the Aeneid represents the continuing influence of ruptured foedera.

All of these connections suggest that the earth's blood-dripping intimates to the reader that Aeneas' crossing over into Europe is itself a kind of violation. The various themes orbiting this passage offer a bold proposal: the graphic imagery attending Aeneas' pulling hastilia from the earth could be interpreted as an inversion of the spearthrowing ritual resuscitated (or invented) by Augustus before declaring war on Cleopatra and Antony, another conflict memorialized as an East-West adversarial axis, most famously depicted on the shield of Aeneas. Instead of throwing the spear to declare war, Aeneas ignorantly pulls it from the ground and reawakens the memory of the conflict that has already been suffused with the landscape he encounters. This is an important moment for Vergil's epic design; he marries the negative forces memorialized in the landscapes to a character marked for his piety. Aeneas is the only hero who might engage with these landscapes positively, an idea expressed in his erection of arae more suitable to the memory of the landscape itself : ergo instauramus Polydoro funus, et ingens/ aggeritur tumulo tellus; stant Manibus arae/ caeruleis maestae vittis atraque cupresso,/ et circum Iliades crinem de more solutae/"And thus we give fresh funerals to Polydorus and heap earth high upon his mound and build our altars to the Shades, with melancholy dark garlands and black cypresses, and around us the Trojan women stand; their streaming hair is loosened as custom bids"(3.62-5). ${ }^{66}$ Aeneas is simultaneously confronted with the full force of ruptured foedera entombed in landscapes and violated arae, while also having the wherewithal to negotiate the pollution inherent in these landscapes. He is at once ignorantly part of the drama of violated foedera as well as the key factor for their solution. His first engagement with Europe is marked by the violation of arae, and yet the actions that follow this initial interaction result in the closure of this violated landscape. A crucial aspect of Aeneas' mission, unknown to him, is that he is in the process of reuniting Europe and Asia, East and West, and as a consequence bringing to finality the accompanying pollution. ${ }^{67}$ 


\section{Reorienting the Orient}

This interplay between arae and foedera and their connection to themes of East-West opposition encourage one to address more formally the poetics of East-West unification in the poem. The remainder of the paper will move beyond altars in order to dissect the configuration of this opposition, while resituating what is at stake when Aeneas sacrifices Turnus in the final lines of the poem.

The opening lines of the Aeneid motivate a reading whereby the cities of Troy and Rome frame and shape our spatial perspective along an East-West continuum, which takes on an added valence once we set these lines in the context of Aeneid 10.90-91:

arma virumque cano, Troiae qui primus ab oris

Italiam fato profugus Laviniaque venit

litora, multum ille et terris iactatus et alto

vi superum, saevae memorem Iunonis ob iram,

multa quoque et bello passus, dum conderet urbem

inferretque deos Latio ; genus unde Latinum

Albanique patres atque altae moenia Romae. ${ }^{68}$

32 The opening seven lines of the Aeneid form a super sentence of unruly subordination that summarizes rather succinctly the main thread of the Aeneid; Aeneas travels from Troy to the region around Rome where he will endure wars because of Juno's ira. The subordinate clause is itself framed by Troiae and Romae. These are the only two cities in the epic, which are absent from the poetic landscape of the Aeneid, except through acts of story telling or prolepsis. Troy no longer exists and Rome has yet to exist within the narrative, yet these two cities transport us across the Mediterranean world, from East to West, as we move from Troia to Roma. Furthermore, Vergil refers to Lavinia litora and Albani patres, both of which are functions of the poetics of alliance of the Aeneid. Lavinium is founded on foedera struck between Aeneas and Latinus in Book 12 ; the Albani are subsumed into Rome after Fufetius violates the foedera fashioned during the certamen of the Horatii and Curiatii (see AUC 1.24) and is drawn and quartered, a punishment depicted on the shield of Aeneas (8.642-5). Implicit in the spaces referenced are those ritual moments known as foedera.

One can add to the poem's opening lines a number of additional examples that highlight a variety of methods that Vergil employs in order to manipulate the audience's perspective of space, which reaffirm this reframing of the conflict between Europe and Asia. Later in Book 1, for example, Juno states to Aeolus : gens inimica mihi Tyrrhenum navigat aequor/Ilium in Italiam portans victosque penatis/"over the Tyrrhenian now sails my enemy, a race that carries the beaten household gods of Ilium to Italy" (1.68-9). Ilium in Italiam not only re-enacts the movement from Troia to Roma, but the shift from East to West is then extended to include the incorporation of one landscape into another imitated not only through Vergil's use of elision to symbolize the process, but also through the paragram of Ilium spilling into Italiam.

Also in Book 1, while reassuring Venus of the fate of her son, Jupiter states :

nascetur pulchra Troianus origine Caesar,

imperium Oceano, famam qui terminet astris,

Iulius, a magno demissum nomen Iulo. ${ }^{69}$

$(1.286-8)$ 
Troianus shifts our perspective to the East. ${ }^{70}$ Four syllables later, Caesar snaps us back to Rome. This movement from East to West in the naming of the Troianus Caesar is then reframed by the subordinate clause to include Oceano, which in effect changes the audience's perspective from Troy and Rome into the conception of this space as bound together within the frontier limits of Oceanus, which then extends to the stars as the line concludes. Yet the space of Ocean and the stars are framed by the hyperbaton Caesar...Iulius, setting the frontier regions of earth and heaven within the name of a single man. The reorientation continues in deriving Roman Iulius from the Trojan Iulus. Iulius and Iulo frame the line, again shifting us in simultaneous snaps between East and West with hardly any differentiation between them, while mixing past, present and future, intertwining the boundaries and expanses of space and time to mere shifts of perspective and alternative viewpoints that collapse, condense and blur large expanses of physical space, metamorphing them into mere terminology, amalgamation, and assimilation. It is this very perspective that Aeneas lacks as he crosses from Asia into Europe.

Subtle allusions in the descriptions of cities continue this theme of spatial ambivalence. In two important insights by Servius regarding Aeneid 2.313 and 2.486, it becomes apparent that the fall of Troy is spatially and temporally loaded :

exoritur clamorque virum clangorque tubarum ${ }^{71}$

plerumque ad tubam evertuntur civitates sicut Albam Tullus Hostilius iussit everti ${ }^{72}$

(ad Aen 2.313)

at domus interior gemitu miseroque tumultu

miscetur, penitus cavae plangoribus aedes

femineis ululant, ferit aurea sidera clamor.

tum pavidae tectis matres ingentibus errant

amplexaeque tenent postes atque oscula figunt. ${ }^{73}$

$(2.486-90)$

at domus interior : de Albano excidio translatus est locus. ${ }^{74}$

(ad Aen. 2.486)

the Annales..$^{75}$ From Carthage Aeneas narrates the ruinous events of the final moments of Troy while unwittingly gesturing to the destruction of his son's city in Alba Longa, an act that is little more than three hundred years in the future (etLongam multa vi muniet Albam. hic iam ter centum totos regnabitur annos gente sub Hectorea. 1.271-2). These subtle conflations of past, present, and future, from Troy to Alba Longa, from Asia to Europe, all lead through urbes captae to the same endpoint, Rome (just as the opening lines move from Troy, to Lavinia, Alba Longa and finally to Rome). This point is well articulated by Livy - another writer who was most assuredly influenced by Ennius' Fall of Alba Longa - Roma interim crescit Albae ruinis (AUC 1.29). The fall of Troy prefigures the Fall of Alba Longa to the Romans - Carthage is not in the equation, yet Vergil has Aeneas connect Troy, Alba Longa, and Rome while sitting in a Carthaginian space. Aeneas' description of the fall of Troy stands for the destruction of every city that both violated foedera and contributed to the expansion of Roman imperium in the process. ${ }^{76}$

This mixing and shifting of the audience's perspective finds its most significant example in Book 6 as Anchises unfolds to Aeneas the mixed lineage of the Trojans and Italians beginning with Silvius - described as Italo commixtus sanguine - and ending with Augustus Caesar : 
quin et avo comitem sese Mavortius addet

Romulus, Assaraci quem sanguinis Ilia mater

educet. viden, ut geminae stant vertice cristae

et pater ipse suo superum iam signat honore?

en huius, nate, auspiciis illa incluta Roma

imperium terris, animos aequabit Olympo,

septemque una sibi muro circumdabit arces,

felix prole virum : qualis Berecyntia mater

invehitur curru Phrygias turrita per urbes

laeta deum partu, centum complexa nepotes,

omnis caelicolas, omnis supera alta tenentis. ${ }^{77}$

(6.777-87)

Anchises points out Romulus and describes his birth in Asian terms through Assaraci sanguinis, an allusion to Phrygia and the grandfather of Anchises. It should not be a surprise that Vergil has set Assaraci between Romulus and the relative pronoun quem; the hyperbaton of Assaraci sanguinis set between Romulus and quem intertwines the founder of Rome and his genetically Trojan lineage. More importantly, line 781 is the only explicit naming of Roma in the Aeneid by a character within the narrative outside of the voice of the poet. Yet, Anchises displaces our mental image of Rome and its seven hills by setting it within a Phrygian realm being circumnavigated by the Berecynthian Mater upon her chariot, wearing a mural crown. ${ }^{78}$ Anchises transports into our mental imagery of Rome the Eastern world of Phrygia, essentially shifting us from an inward perspective of Rome - highlighting the seven hills and the continuous wall - to an outward perspective of cities being connected through the journey of Cybele. And yet the reference to Cybele transports us back inside the walls of Rome to the Palatine Hill where the goddess in her temple could look out over the ludus Troiae taking place in the Circus Maximus (while Augustus's quarters lied in between the temples of Cybele and Apollo). Or she points us to coinage where her image signified triumph and world empire, a point Vergil alludes to by setting her on a chariot. ${ }^{79}$ Inside and outside become alternative points of view, which offer the same significance of meaning: Rome and Troy, present and past, Europe and Asia, West and East and vice versa are merely ways of approaching the same object. ${ }^{80}$ The binary essentially becomes Janus-faced.

The mention of cities in the Aeneid is always important, and the above case with regard to Phrygias....urbes is of special significance considering that Aeneid 3 is a narrative about the founding of Phrygian cities. I do think that Anchises' statement is meant to recall Book 3 in which the cities Aeneadae/Aineia, Pergamea, and Buthrotum are founded, making the journey of the Berecynthian mother a kind of re-enactment of the Trojan journey in Book 3. Amidst this theme of colonization is the transformative power of the Trojans upon the landscape of the Mediterranean world either through city-building itself or through the force of their descriptive speech acts. It is from this perspective that we can counter the negative valence of the arae in the context of violated foedera ; Aeneas is reorganizing the spatial antagonism of the epic landscape he moves through.

41 The first description of landscape in Book 3 is not so much transformative as it is programmatic :

diversa exilia et desertas quaerere terras auguriis agimur diuum, classemque sub ipsa

Antandro et Phrygiae molimur montibus Idae. ${ }^{81}$ 
After the burning of Troy, the Trojans meet at that famously Phrygian location of Mount Ida. On Delos, the second stop of the Trojan journey, Anchises puts the programmatic language into practice as his description of Crete moves from a traditional account of the island as the birthplace of Jupiter and the island of one hundred cities to a less traditional Crete incorporated into Phrygian landscape :

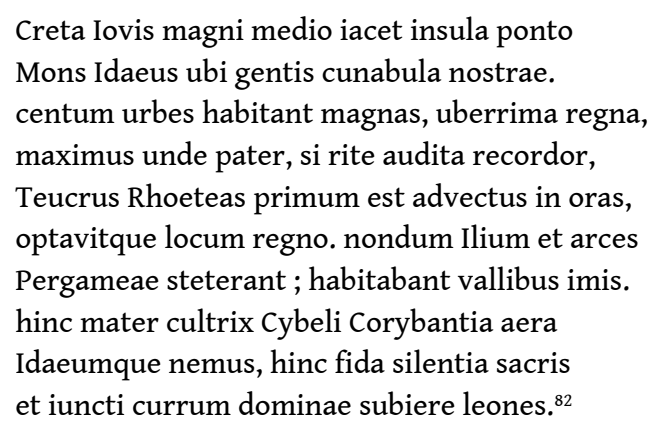

In Anchises' description of Crete we find that the island was, for all intents and purposes, a former Troy. It has its own Mount Ida, Idaean Grove, Cybele and her cultic activity. Troy and Crete are linked, making Crete and Troy a single unit snapping the imagery from the middle of the pontus to Asia, conflating each landscape into an indistinguishable image of the other. Furthermore, Teucrus highlights the productive capacity for Trojan city-building ; Teucrus' activity on Crete results in the flourishing of a 100 great cities. The Trojan journey under the guidance of Aeneas is continuing this trend, a trend that will persist under the Romans.

As the Trojans move from Crete to Buthrotum Vergil manipulates our expectations of space by directing our attention away from the Idaean Grove of Crete to the urban setting of Buthrotum's Troy, in essence transforming the space between Crete and Buthrotum into a kind of imaginary Troad :

procedo et parvam Troiam simulataque magnis

Pergama et arentem Xanthi cognomine rivum agnosco, Scaeaeque amplector limina portae ; nec non et Teucri socia simul urbe fruuntur. ${ }^{83}$

effigiem Xanthi Troiamque videtis

quam vestrae fecere manus, melioribus, opto, auspiciis, et quae fuerit minus obvia Grais.

Si quando Thybrim vicinaque Thybridis arva intraro gentique meae data moenia cernam, cognatus urbes olim populosque propinquos, Epiro Hesperiam (quibus idem Dardanus auctor atque idem casus), unam faciemus utramque Troiam animis : maneant nostros ea cura nepotes. ${ }^{84}$

Though Buthrotum is a bit repressed (to say the least), its meaning transcends the meekness of its physical presence. ${ }^{85}$ It is of particular significance that Buthrotum was in fact an actual Roman colony, like Carthage, and that its nomenclature as parva Troia simulataque is echoed later by Aulus Gellius in his description of Roman colonies as effigies parvae simulacraque esse (Attic Nights 16.13.9). ${ }^{86}$ Buthrotum departs from its meager monumentality and becomes a linchpin between Epirus and Hesperia, as the elision emphasizes, and in essence the parva Troia becomes the ironic counterpart to 
magnaGraecia, a landscape that finds itself squeezed in between the elision itself. Aeneas ends his valediction with a promise that each city will be made a single Troy through the force of their animis, a phrase that Servius connects to the discourse of foedus. ${ }^{87}$ Aeneas' statement not only connects Greece to Italy and Buthrotum to Rome, but the polysemy of Troia forms a bond between Asia and Buthrotum which then extends through to Italy resulting in the union of Asia, Greece and Italy through the parvaTroia.

I think this mixing of landscapes and cities is confirmed upon the final episode of Book 3 when the Trojans encounter the forgotten crewmember of Odysseus' ship Achaemenides. As the Trojans approach Sicily they see him :

cum subito e silvis macie confecta suprema

ignoti nova forma viri miserandaque cultu

procedit supplexque manus ad litora tulit.

respicimus. dira inluuies immissaque barba,

consertum tegimen spinis : at cetera Graius...8

sum patria ex Ithaca, comes infelicis Ulixi

$(3.590-4)$

nomine Achaemenides, Troiam genitore Adamasto

paupere (mansissetque utinam fortuna !) profectus. ${ }^{89}$

When Vergil describes Achaemenides with the curious terms nova forma and ignoti he is in fact telling us something we already know - Achaemenides is something new in poetry, especially in comparison to Polyphemus who is both seeking known shores (litoranota petentem 3.657) and has himself been sought again and again by previous poets. However, the full innovation of the episode is found in the multiple significations inherent in the polysemous potential of the vagabond's name. Achaemenides means the waiting Achaean - to be more accurate, the son of the waiting Achaean. ${ }^{90} \mathrm{He}$ is also an Ithacan. In his name and his homeland we are struck by his Greekness. Yet his name has further connotations recalling the Persian Achaemenid dynasty. This polysemous appellation operates on three simultaneous spatial levels, all of which snap our mental gaze from West to East, moving from Sicily, to Greece, to Persia. When the Trojans accept Achaemenides, we again encounter another instance of integration, but as opposed to assimilating Rome and Troy, or Troy and Alba Longa, or various landscapes to Phrygia, we have the integration of Greece, Asia and Hesperia bound up together into a single moment of supplication and acceptance.

The space formed and shaped by Rome and Troy and then the epic landscape becoming over-mapped by Trojan imagery is something that seems to be closely connected to the acceptance of Achaemenides at the end of Book III. I do believe that we are meant to understand this continual theme as the blurring and then the annihilation of the traditional Greek frame of East and West within the context of alliance. It is notable that this act of acceptance is described as the following: ipse pater dextram Anchises haud multa moratus/ dat iuveni atque animum praesenti pignore firmat/"Father Anchises does not wait long to offer his hand and steadies the young man with that strong pledge" (3.608-9). Anchises performs the iunctio dextrarum, an act that orbits the ideology of foedus, especially in the context of pignus, a word that implies the surety inherent in accepting one into a relationship of hospitium or amicitia based on fides (see AUC 22.58.6, 25.16.14, 40.47, 42.39 to name only a few examples from a single author). We can add to this idea the following line at Aeneid 11.363 where pignus seems to be related closely to foedus: nulla salus bello, pacem te poscimus omnes,/ Turne, simul pacis solum inuiolabile 
pignus/"There is no safety in war. What all of us are asking you, Turnus, is peace peace and the only thing that is the inviolable pledge of peace." An inviolable pignus of peace is closely related to foedus,as AUC 2.13.9 shows : et Romani pignus pacis ex foedere restituerunt. Given the spatial and political symbolism of this moment in the narrative, in addition to the iunctio dextrarum and its relation to pignus, I think it is advisable to see the discourse of alliance activated..$^{91}$ This polysemous and symbolic moment responds to the ruptured foedera that began the epic cycle, but here we are meant to see the unification of East and West through the allusion to the historical clan of the Achaemenids. When Anchises states in Book 3, sed quis ad Hesperiae venturos litora Teucros crederet?/"But who would believe that the Teucrians would go to the shores of Hesperia" (3.185), this is not merely a rhetorical question. What he is really asking is : who would believe that East would go West? It is an astonishing insight on Anchises' part. Anchises is aware that the Trojans are in the process of reorienting the orient.

The East-West binary is a curious model by which to describe space and the relationships between landscapes. Its meaning derives from oppositions that fail to acknowledge an implicit paradox between the binary. It is this paradox that makes Troy so vital in conceiving of Vergil's poetic space and his manipulation of geographies. Any boundary between entities implicitly involves a tripartite relationship : the two objects which are separated from one another by the boundary and the boundary itself, which is in a state of liminality between the two entities. In the present case, the binary of East and West implicitly contains a space that is neither East nor West, at the very point of separation itself. I would like to suggest that the space between the binary was for the Romans Troy. Catullus 68 in fact highlights the idea of Troy as a liminal zone between East and West, or in Catullus' words Asia and Europe - though it must be remarked that Catullus' Troia is something quite different than that of Vergil :

Troia (nefas !) commune sepulcrum Asiae Europaeque,

Troia uirum et uirtutum omnium acerba cinis. ${ }^{92}$

Troy is a liminal city - or in his terms - a shared tomb of both Asia and Europe. The elision mimics the idea, a fact further highlighted by the first reference in Western literature to Eurasia. Troy is a space where the binary dissolves, forming an amalgamation of landscape that is both East and West, yet outside of East and West, a place where Trojans can become Greeks as in the case of Aeneid 2 or where East can become West in the case of Aeneid 3. I do not think one would be incorrect in stating that Troy is the man-made structure that divides the ancient world between Asia and Europe, corresponding to the natural landscape of the Hellespont..$^{93}$

This idea is somewhat problematic with regard to the Aeneid. If we are in agreement that Troy is the boundary between East and West and is also the shared space between them both, then we encounter an interesting dilemma upon Aeneas' description of Troy at the beginning of Book 3 ; Aeneas tells us that all of Neptunian Troy is smoking on the ground. The marker that had divided East and West no longer exists. In essence, East and West are no longer in a binary opposition prefigured by a man-made liminal zone separating them, but both exist in the Trojan expedition itself as it moves from East to West. The Trojans are a walking, talking, breathing, moving liminal zone. Wherever they go, they change the boundaries and demarcations establishing not binary oppositions, but instead, places of mixing and commingling. The most salient feature of this mixing and commingling is the unification of Asia and Europe itself. The 
Romans have retained this unique Trojan quality even if Trojan dress and language has been obliterated according to the foedus enacted between Juno and Jupiter in Book 12.

We in fact encounter a proof of this assertion in Book 1, but in an unlikely context. Aeneas describes his wanderings to Venus in Book 1.384-5 in this way, ipse ignotus, egens, Libyae deserta peragro,/Europa atque Asia pulsus/"and I myself, a needy stranger, roam across the wilderness of Libya ; I am driven out of Europe and Asia." Because the Trojans are innately liminal, they are in essence inhabitants of both Asia and Europe simultaneously. If they are unable to live in Europe and Asia, then it seems only natural that they reside in a place that is neither East nor West, neither Europe nor Asia, that is Africa/Libya (and symbolically, Egypt). For Aeneas he must either exist in Europe and Asia simultaneously, or he must exist outside of them both. In this case Libya, and by synecdoche Africa, is the only place the Trojans might inhabit, as Mercury himself seems to suggest when he rebukes Aeneas for dressing like a Tyrian at $4.262-3 .{ }^{94}$ But by doing so they will deny their liminality and their unique positions within the Mediterranean geography. Europa atque Asia in fact highlights this idea. This phrase is as close as Latin can come to saying Eurasia since the elision connects Europa to Asia into a single mass, in essence uniting East and West. The verbal artifact is charged with political and symbolic potential.

This statement by Aeneas is all the more impressive upon reflection of the key lines at 10.90-1: quae causa fuit consurgere in arma/ Europamque Asiamque et foedera solvere furto. We encounter this impressive elision, ending at the caesura, at which point Juno refers to the loosening of foedera through the rape of Helen. Juno highlights the fact that Europe and Asia used to be united - stressed by the elision - until the violation of foedera. The elision and caesura symbolize the movement from unification to separation and antagonism. But because of his unique relationship to Eurasia, Aeneas is in the process of reuniting the two continents into a unified whole. Aeneas interprets his journey as a sign that he has been repulsed by Eurasia, without realizing that his journey has in fact reunited them.

These lines become all the more symbolically charged upon consideration of Servius' comments in which he discusses the debate over whether the orbis is divided into two or three parts. ${ }^{95}$ There was debate over whether the Mediterranean landscape was considered to be three or two continents. I strongly assert that Aeneas is well aware that he has landed in a place outside of Europe and Asia. This is a crucial point to understand because while Vergil is uniting East and West through the journey of Aeneas, he is simultaneously reorganizing the antagonistic axis along a North-South, or Eurasia-Africa axis. We need only to remember the discussion of the Arae, which began this long discussion in order to see that one theme of the Aeneid is the realignment of the epic cycle along a new kind of foedera that reconfigures the tensions and ideologies inherent in the epic landscape Vergil inherited. But the Arae in Book 1 implicitly acknowledge that Carthage has paid the ultimate price for violating its foedera with Rome, not only losing its control over Sardinia and Sicily, but also suffering complete annihilation and then colonization by Rome. Even as Vergil is realigning the adversarial axes, he is simultaneously suggesting that East, West, North, and South are becoming a unified whole from the global perspective of the poem.

We can approach this material from another angle; the arae of Tatius and Romulus depicted on the shield of Aeneas embody the role arae and foedera play in the poetics of this unification of space discussed above. Servius clearly understood that foedus brings 
to realization the nature of Roman etiology as a function of ethnic amalgamation. Servius alludes to the logic that informs the Vergilian foedus in a remark at Aeneid 12.198 : Latonaeque genus duplex Ianumque bifrontem.

LATONAEQUE GENUS DUPLEX ac si diceret, utrumque sexum prolis Latonae vel subolis. et bene in foederibus duplicia invocat numina, quia in unum duo coituri sunt populi. IANUM quoque rite invocat, quia ipse faciendibus foederibus praeest: namque postquam Romulus et Titus Tatius in foedera convenerunt, Iano simulacrum duplicis frontis effectum est, quasi ad imaginem duorum populorum. ${ }^{96}$

(ad Aen 12.198)

Servius tells us that the genus duplex and the famous double face of Janus symbolize in different ways the process of two ethnicities becoming a single entity (quia in unum duo coituri sunt populi and Iano simulacrum duplicis frontis effectum est, quasi ad imaginem duorum populorum), and furthermore that Janus is invoked in the performance of foedera and that his duplex frons is an imago of two populations. ${ }^{97}$ The first Romanfoedus performed by Tatius and Romulus is memorialized by a double face that signifies ethnic merging. Earlier ad Aen. 1.291 Servius discusses the same idea ; after the foedus had been made (facto foedere) Tatius and Romulus built the temple. He then gives a series of explanations for the meaning of Janus' two faces as proposed by the alii : they represent a coitio of the two kings or symbolize the "reversion" to peace by parties who are about to embark on war. ${ }^{98}$ The explanations are set in contrast to Servius' own interpretation of the duplex frons' significance in his comments in Book 12 where unification of two populations is the overriding idea. The double face of Janus is actually a mirror or imago of Rome itself, a symbol of the continual merging of multiple ethnicities into one, and yet the double face reflects the limits of full amalgamation.

Servius' theory of the double-faced Janus offered in his reading of Book 12 is quite consistent with the thematic patterns within the Aeneid itself. We see confirmation of this from the divine perspective of the poem : first in Book 4, where the first usage of foedus can be found in direct speech, ${ }^{99}$ then in Book 12, when Juno and Jupiter agree to foedera. ${ }^{100}$ Both passages reflect the idea of making two nations one, and that part of this unification is the mixing of cultures into a novel syncretism. The gods are aware that implicit in the formation of foedera is the mixing of cities and peoples. One gets the sense that Servius had come to this conclusion by the time he reached Book 12 where he offered his own interpretation of the meaning of the double face of Janus.

In the course of the epic, however, the theme of spatial and political unification swings pendulum-like between those moments of fruitful unification and those of atomization and catastrophe. Violated arae intimate that the pendulum has swung to the side of strife. These negatively charged arae are part of the aftermath of violated foedera that have permeated the poetic landscape of the epic cycle prior to the events of the Aeneid. From a certain perspective we can say that the Aeneid both continues the theme of violated foedera that shaped the narrative of the epic cycle as a whole, while simultaneously creating a new epic landscape where violated foedera are replaced by a stable system of alliance that breaks the wheeling cycles of violence. ${ }^{101}$ This last point is significant since it casts in high relief the foedus of Aeneid 12. The death of Turnus in the fulfillment of the infected foedus actualizes both conditions of Aeneas' oath as we remarked above, but just as importantly, within the epic landscape of the Aeneid this foedus brings to a close the theme of altar violation and ruptured alliances. There must be a last epic foedus that both confronts the problems of ritual pollution preceding it, while bringing into being a new system of alliance. The foedus of Romulus and Tatius 
and the temple of Janus, built as a symbolic artifact of the nature and consequences of Roman foedera, reflect the successful transition of alliance from the epic cycle, upon which the Aeneid is built, to Roman history and a new poetics of alliance.

\section{NOTES}

1. Gian Biagio Conte, The Rhetoric of Imitationoui sur d'accord: Genre and Poetic Memory in Virgil and other Latin Poets, trans. Charles Segal (Ithaca : Cornell University Press, 1986) 167.

2. See Philip Hardie, The Epic Successors of Virgil : A Study in the Dynamics of a Tradition (Cambridge : Cambridge University Press, 1993) 11-18.

3. For recent approaches to these issues, see J.D. Reed, Virgil's Gazeoui sur d'accord : Nation and Poetry in the Aeneid (Princeton University Press: Princeton, 2007); Brent Hannah, "Manufacturing Descent: Virgil's Genealogical Engineering," Arethusa 37 (2004) 141-64 ; Eve Adler, Vergil's Empire : Political Thought in the Aeneid (Rowman \& Littlefield Publishers : USA, 2003). To quote Reed (38), who uses focalization to diagnose the process of the poem's various configurations, "Euryalus is a Trojan, Pallas an Arcadian Greek settled in Latium, Lausus an Etruscan, Camilla an Italian, specifically a Volscian from Privernum. The first two die fighting for Aeneas, the later two against him, but all four belong to peoples that will be absorbed into the new nation that is eventually to become Rome." Reed is particularly interested in the absent ethnicity in this process of subsumation, that of Rome. This conception of the poem can be generally applied to many of its spatial and temporal features. Conflation and subsumation are essential.

4. Outside of Aeneid 12, Livy AUC 1.24 is the fullest account of the ritual act of a foedus. Foedera were overseen by the college of fetial priests who pronounced the oath/curse of the foedus and sacrificed a piglet in order to sanctify the conditions (leges) of the foedus. Foedera were closely connected to the creation of fines between Rome and its allies. Foedera not only constructed the conditions for interstate alliances (and they varied depending on the proximity to Rome), but they organized the spatial boundaries between empires (as is the case of the foedera between Carthage and Rome), defeated nations (as is the case of Carthage after the 2nd Punic War), or other allies (as is the case in the foedus between Rome and Antiochus). Foedera establish formal spheres of influence. I am currently writing a full-length study on the poetics of alliance and the role of foedera in Roman literature.

5. By Servius I mean the aggregation of interpretations that have grown around the commentary under his name.

6. It must be noted that this cluster of rocks function as the first landscape (sequentially speaking) the Trojans encounter. Orontes' name consequently points the reader to the coast of Asia and the Orontes river, known also as Typhon and Draco. His name creates a spatial ambiguity, whereby a very Italian space (noted by the Itali naming the rocks) encounters an Asian river. On Orontes' death as a human sacrifice see James O'Hara, Death and the Optimistic Prophecy in Vergil's Aeneid (Princeton University Press : Princeton, 1990) 22.

7. For the significance of the Arae as an “etymological signpost” see O'Hara (1990) 19-22.

8. "Moreover, these rocks are between Africa, Sicily, Sardinia and Italy, and they are called "Altars" by the Italians because at that place the Africans and Romans entered into a foedus and 
wished that the boundaries of their Empires be there. For this reason Dido (4.628) prays that shores are contrary to shores, waters to waves." All translations are my own, unless otherwise stated. 9. We must also add the possibility that the Arae mirror the Ara which was established in the caelum by Jupiter after his victory over the Gigantes. Manilius describes them in this way, ipsius hinc mundo templum est, victrixque solutis/ Ara nitet sacris, vastos cum Terra Gigantas/ in caelum furibunda tulit (Astro. 1.420-2).

10. The foedus referenced must be prior to the first Punic War because of the presence of Sardinia and Sicily in the terms of the foedus. In fact Sardinia, Sicily and the Arae all operate as the fines between Roman and Carthaginian imperium. See J. Serrati, "Neptune's Altars: The Treaties between Rome and Carthage (509-226 BCE)," CQ 56 (2006) 113-34 on the dating of this treaty as 306 BCE and discussion of the various historical sources Servius mentions.

11. While foedus does not actually occur in the text at this point in the narrative, I think it is safe to assume that a Roman reader would have understood the political etiology for the naming of these rocks as Arae. That is to say that the Arae signify an ancient foedus with Carthage, and given the vast tradition of exegesis Servius discusses, which suggests more than an obscure reference, I think that we can read the poetics of alliance into the Arae.

12. See also Pamela Bleisch, "Altars Altered: The Alexandrian Tradition of Etymological Wordplay in Aeneid 1.108-12”, AJP 119 (1998) 599-606. Bleisch's discussion of the wordplay between arae (altars) and the Greek word for curses, aria, is important for the entire discussion that follows.

13. Cicero's comments on Gallic human sacrifice are apt : ab isdem gentibus sanctis et in testimonio religiosis obsessum Capitolium est atque ille Iuppiter cuius nomine maiores nostri vinctam testimoniorum fidem esse voluerunt. postremo his quicquam sanctum ac religiosum videri potest qui, etiam si quando aliquo metu adducti deos placandos esse arbitrantur, humanis hostiis eorum aras ac templa funestant, ut ne religionem quidem colere possint, nisi eam ipsam prius scelere violarint? quis enim ignorat eos usque ad hanc diem retinere illam immanem ac barbaram consuetudinem hominum immolandorum ? quam ob rem quali fide, quali pietate existimatis esse eos qui etiam deos immortalis arbitrentur hominum scelere et sanguine facillime posse placari? cum his vos testibus vestram religionem coniungetis, ab <his> quicquam sancte aut moderate dictum putabitis? Pro Fonteio 31)

14. "This entire passage concerning the foedera has been translated from Homer where Alexander Paris is about to battle with Menelaos in single combat."

15. See Tilman Schmit-Neuerburg, Vergils Aeneis und Die Antike Homerexegese : Untersuchungen zum Einfluss ethischer und kritischer Homerrezeption auf Imitatio und Aemulatio Vergils (Walter de Gruyter : Berlin, 1999) 296-300.

16. "Surely he leads one to compare this passage to the Homeric foedus: for just as in that one there is Priam, thus here is Latinus ; just as here is Aeneas, so there is Agamemnon. And those who pray first will preserve the foedus, but those who give their oaths last rupture it, just as there the Trojans through Pandarus, and here the Latins through Tolumnius."

17. See Schmit-Neuerburg (1999) 318-25 highlights the fact that Pandarus' actions have been divided between Tolumnius and Messapus, but he does not comment on the significance of this.

18. See Iliad 3.264-309 and Aeneid 12.163-215 for a description of the entire ritual.

19. On this point see Renaud Gagné, "The Poetics of Exoleia in Homer," Mnemosyne 62 (2009, forthcoming) $16 \mathrm{p}$.

20. To quote Hardie (1993) 12, "[T] his is partly the achievement of the end of the poem, which as so many have felt is not an ending at all (except for Turnus), merely a beginning of the history of the Aeneadae once they have vindicated their right to settle in the land of future Rome." of course we must add the lens of the underworld where those who have yet to begin (their lives) are also located where those who have ended their lives exist, conflating the idea of beginning and ending, past and future. On the many endings of the Aeneid see also Hardie, "Closure in Latin 
Epic," Classical Closure, eds. Roberts, Dunn, and Fowler (Princeton University Press : Princeton, 1997) 142-51.

21. See Julia Dyson, King of the Wood: Sacrificial Victor in Virgil's Aeneid (University of Oklahoma Press : Norman, 2001) 95-6 for an apposite discussion.

22. See Y. Syed, Vergil's Aeneid and the Roman Self: Subject and Nation in Literary Discourse (University of Michigan Press : Ann Arbor, 2005) 134.

23. On the Iliadic material see Gagné (2009).

24. Frances Hickson Hahn, "Vergilian Transformation of an Oath Ritual: Aeneid 12.169-174, 312-315," Vergilius 45 (1999) 24. For a brief discussion, see also C.J. Mackie, The Characterization of Aeneas (Scottish Academic Press : Edinburgh, 1988) 190-6.

25. "And the Laurentians charge against them ; but here again the compact ranks of Trojans pour out-together with Agyllines and Arcadians with ornamented armor. They all have just one passion : for the sword to settle the dispute. They strip the altars for firebrands; across the skies a dense tempest of shafts, a rain of iron falls. Within the storm some of the Latins carry libation cups and braziers toward the city. And king Latinus, bearing back his repulsed gods and the infected treaty, now retreats." (All translations of the Aeneid are by Mandelbaum).

26. We should also see this episode in dialogue with the battle of Actium, which Hardie connects to the storm in Book 1. See Hardie (1986) 97-110.

27. See Gagné (2009) 9 on this point.

28. See Schmit-Neuerburg (1999) 322-3.

29. On piacula in the Aeneid generally see Dyson (2001) 29-49

30. For references connecting foedus to the sacrifice of a piglet foede see TLL 1002.4-13. This connection can probably be dated back to Verrius Flaccus. Foedus and foeditas are not actually related. See Michiel de Vann, Etymological Dictionary of Latin and the other Italic Languages (Brill : Leiden, 2008).

31. We should add to this violation the Trojans' cutting down the sacred tree of Faunus (12.766-90) discussed by Dyson (2001) 221-7.

32. "But if the war is settled in our favor by victory (as I should rather judge, and may the gods confirm this with their will), then I shall not subject Italians to Teucrians, ask kingdoms for myself : both nations, undefeated, shall accept the equal laws of an eternal contract."

33. Adler (2003) 183 interprets these lines as the validation that "the foundation of Rome is a peace treaty," without recognizing that all the options Aeneas sets out do in fact come to pass. Though I do (generally) agree with her sentiments as stated at 187, worth quoting: “[A]s Aeneas' founding of Rome was his imposing a peace treaty to unite the Trojan and Italian peoples through an innovation of their common rites and gods, so the perfected founding of Rome will be the peace treaty unifying the Romans with all the peoples of the world through this same innovation." We must differentiate the scope of the poem in non-Italian versus Italian contexts. The full actualization of this process is directly dependent upon these primordial foedera that are not as positively presented as Adler suggests. It is through bloodshed and its finality through peace that brings Adler's view of the poem into focus. But within the scope of the poem this bloodshed is ultimately derived from flawed attempts at peace. Having said that, Adler (189) does hit upon an important conclusion, but from the point of view of ruler-gods, "(U)nder the dispensation of the universal Roman ruler-gods, the imposition of the habit of peace takes on a peculiar character because war itself can no longer be conceived as the contest of nation, but only Civil War, or, from another point of view, as guilty violation of divine law. The narrative of the Aeneid shows what is meant by the transformation of foreign into Civil War by showing the transformation of Italians and Trojans, in the very war between them, from foreigners into fellows-fellow Romans." My only disagreement with this argument is that Civil War has nothing to do with ruler-gods and any violation of divine law is directly connected to the violation of the foedera that bind the ur-Roman peoples. 
34. See Clifford Ando, "Vergil's Italy : Ethnography and Politics in First-Century Rome," in Clio \& the Poets : Augustan Poetry and the Traditions of Ancient Historiography, eds. Levine and Nelis (Brill : Leiden, 2002) 123-42.

35. Although Aeneas' oath does not contain a curse (like that we find in Iliad 3), it is perhaps advisable to surmise the implicit presence of the curse that we find at Livy, AUC 1.24: "Audi" inquit, "Iuppiter; audi, pater patrate populi Albani; audi tu, populus Albanus. Vt illa palam prima postrema ex illis tabulis ceraue recitata sunt sine dolo malo, utique ea hic hodie rectissime intellecta sunt, illis legibus populus Romanus prior non deficiet. Si prior defexit publico consilio dolo malo, tum ille Diespiter populum Romanum sic ferito ut ego hunc porcum hic hodie feriam ; tantoque magis ferito quanto magis potes pollesque."

36. For the war with Carthage being built into the foedus between Juno and Jupiter due to the Ennian intertext, see D. Feeney, "The Reconciliations of Juno," CQ 34 (1984) 179-94. It must be stated that although Juno has shaped the future landscape of war within the movement of Roman history, her final line is ironically unfulfilled (occidit, occideritque sinas cum nomine Troia : 10.828) as the building programs under Augustus in Troy attest. It is appropriate to quote Dyson (2001) 18 on this point, "[I]t may be that Juno is pacified only by the promise of endless human sacrifices. The final interview between her and Jupiter points in several ways toward a dark future for Aeneas and his people. Parallels with the conversation between Jupiter and Mercury in Book 4, which leads to a new series of adventures for Aeneas, imply, that Juno, too, may be at the beginning rather than the end of her intervention in Aeneas' affairs." Dyson expands on her thoughts in 125-130 where she argues that Juno "is pacified only by the promise of endless human sacrifices." She concludes this discussion with Perusia (130). Perusia plays a role only in so far as it is part of the vast network of Italian killing Italian, Roman killing Italian, and Roman killing Roman.

37. Ecce viro stridens alis adlapsa sagitta est,/ incertum qua pulsa manu, quo turbine adacta,/ quis tantam Rutulis laudem, casusne deusne,/ attulerit; pressa est insignis gloria facti,/ nec sese Aeneae iactavit vulnere quisquam (12.319-23). Although the poet states that this deed might bring praise to some Rutulian, he undercuts this statement by stating that casus or a deus may have been responsible. This absence of knowledge by a poet whose gaze spans all time and space is crucial. It is just as likely that a non-Italian's arrow hit Aeneas. Either the poet does not know or he chooses to keep silent on the culprit.

38. ille Sychaeum /impius ante aras atque auri caecus amore/clam ferro incautum superat,/ securus amorum/germanae; factumque diu celauit et aegram/ multa malus simulans uana spe lusit amantem.

39. vix tandem, magnis Ithaci clamoribus actus,/ composito rumpit vocem et me destinat arae. Servius ad Aen. 2.134: ergo vincula religionis intellege, ut "et vinclis innaret Cloelia ruptis," scilicet foederis.

40. qualis mugitus, fugit cum saucius aram/ taurus et incertam excussit ceruice securim. Dyson (2001) 105 reads the simile as the "worst possible omen" in terms of sacrificial ideology.

41. See Dyson (2001) 98-103 for the ritual reversals of this episode and the sacrificial repayment for the Trojans' donning the armor of their enemies.

42. uidi ipse furentem/caede Neoptolemum geminosque in limine Atridas,/ uidi Hecubam centumque nurus Priamumque per aras/sanguine foedantem quos ipse sacrauerat ignis.

43. accessi uiridemque ab humo conuellere siluam /conatus, ramis tegerem ut frondentibus aras,/ horrendum et dictu uideo mirabile monstrum.

44. Ergo insperata tandem tellure potiti/ lustramurque Ioui uotisque incendimus aras,/ Actiaque Iliacis celebramus litora ludis.

45. Annales 1.10 : sane Cassii et Brutorum exitus paternis inimicitiis datos, quamquam fas sit privata odia publicis utilitatibus remittere: sed Pompeium imagine pacis, sed Lepidum specie amicitiae deceptos; post Antonium, Tarentino Brundisinoque foedere et nuptiis sororis inlectum, subdolae adfinitatis poenas morte exsolvisse.

46. et geminas, causam lacrimis, sacrauerat aras. 
47. ast illum ereptae magno flammatus amore/ coniugis et scelerum furiis agitatus Orestes/ excipit incautum patriasque obtruncat ad aras.

48. stant arae circum et crinis effusa sacerdos/ ter centum tonat ore deos, Erebumque Chaosque/ tergeminamque Hecaten, tria uirginis ora Dianae.

49. dixerat haec, adytis cum lubricus anguis ab imis/ septem ingens gyros, septena uolumina traxit/ amplexus placide tumulum lapsusque per aras,/ caeruleae cui terga notae maculosus et auro/ squamam incendebat fulgor, ceu nubibus arcus/ mille iacit uarios aduerso sole colores; tum uero attonitae monstris actaeque furore/ conclamant, rapiuntque focis penetralibus ignem,/ pars spoliant aras, frondem ac uirgulta facesque/coniciunt. It is debatable whether the women destroy the arae to Anchises or the four arae to Neptune referred to at 5.639, although given their wish to remain in Sicily, the violation of arae to Neptune seems like a logical act by people who do not wish to sail.

50. post idem inter se posito certamine reges/armati Iouis ante aram paterasque tenentes/ stabant et caesa iungebant foedera porca.

51. I omitted a few references to arae like the 100 arae of Jupiter Hammon beside which Iarbas prays (4.204). The multitude of arae results in the fulfillment of his prayer, which ultimately results in the flight of Aeneas and the death of Dido. Furthermore, the arae used by the Sibyl or the arae promised by Iulus if he should kill Remulus are also omitted since they appear to fall outside of the pattern. Furthermore, an analysis of altaria will show that they are rarely found in the context of violation.

52. See Hardie (1986) 110-18 on the connections between the Cacus episode and Civil War. This episode is likewise connected to the storm in Book 1, Actium of Book 8, and the foedus of Book 12 (by association).

53. "Since the Trojans had promised her out of deceit, Paris concealed himself behind a statue of Thymbraean Apollo, and he wounded Achilles as he approached the foedus with a shot arrow, then while dying Achilles demanded that after Troy was conquered Polyxena should be sacrificed at his grave, which Pyrrhus fulfilled." Servius auctus continues as follows : et alius ordo fabulae huius : cum Graeci victores in patriam vellent reverti, e tumulo Achillis vox dicitur audita querentis, quod sibi soli de praeda nihil inpertivissent. de qua re consultus Calchas cecinit, Polyxenam Priami filiam, quam vivus Achilles dilexerat, eius debere manibus immolari ; quae cum admota tumulo Achillis occidenda esset, manu Pyrrhi aequanimiter mortem dicitur suscepisse. invenitur enim apud quosdam quod etiam ipsa Achillem amaverit, et ea nesciente Achilles fraude et insidiis sit peremptus.

54. For a complete discussion of the variations, see Timothy Gantz, Early Greek Myth, vol. 2 (The Johns Hopkins University Press : Baltimore, 1993) 628.

55. Dictys Hist., Fragmenta (Jacoby, FGrH, 1a.49.F ; fragment 7a. 24-25).

56. "To loosen the foedera by deceit : it is read in the historical renderings that the Trojans had a foedus with the Greeks. At that time Paris was also taken into hospitality and thus committed adultery. Therefore 'to loosen the foedera by deceit' ruptured the alliance of friendship by adultery : for 'theft' is adultery, from where comes 'even sweet deceits.' This is the actual reason why Troy was destroyed: for foedera which existed between the Greeks and Trojans were ruptured thusly. Since Ilium had been besieged and Hercules had given the daughter of Laomedon, Hesiona, the sister of Priam, to Telamon, legates came with Priam and they were little able to reclaim her, since the Greeks were saying that they had her according to the law of war. For this reason Priam, completely upset, sent Paris with an army, so that he might bring back an equivalent recompense, whether the wife of the king, or his daughter. He seized Helen after Sparta fell. Therefore, in this passage Vergil touches on both narratives, both that historia which we just outlined and on account of the judgment of Paris, although that matter is a fabula and made up by the poets. 'To loosen foedera by deceit' whether because he snatched Paris from death although he was beaten, or because Pandarus ruptured it so that it was through trickery." Servius auctus adds other possibilities for these lines : FOEDERA SOLVERE FVRTO] an quod Paridem victum a Menelao subripuit morti? an quod Pandarus dissipavit, ut sit 'per furtum'? 
57. Alan Cameron Greek Mythography in the Roman World (Oxford University Press : Oxford, 2004) 90-91 states that historia "is a matter of fact or subject matter in a classical text, as opposed to a detail of language or a rhetorical trope" and included both the subject matter that required elucidation and the "elucidation itself." See also David Dietz, "Historia in the Commentary of Servius," TAPA 125 (1995) 61-97. S.J. Harrison, Vergil : Aeneid 10 (Oxford University Press : Oxford, 1991) states that Servius is perhaps making up this reference to historiae. Once it is realized that we are dealing with plausible interpretation of fabulous events (something the Roman historiographers regularly did), rather than with an actual source, we are better able to see that Servius is referring to rationalizations of the rape of Helen through his notion of historia as stated in his introductory comments to the Aeneid. This precise historical interpretation must have been current at the time of the Aeneid because Juno herself uses the language of law and alliance between nations to describe the rape of Helen. There is no fabula in her interpretation of events; in fact her interpretation is historia and is another moment where historia and fabula are mixed in the narrative.

58. This point highlights well Hardie's discussion of epic continuity and repetition where the ending of one poem is the beginning of the next where repetition ensues, but in the present case we see that the internal structure of this continuity is based on the violations of foedera. See Hardie (1993) 11-18.

59. See Putnam (1998) 202 for the connection of this line to the baldric of Pallas. Vergil (and Lucretius) owe something to Ennius here : cui nec arae patriae domi stant, fractae et disiectae iacent,/ fana flamma deflagrata, tosti/†alii† stant parietes,/deformati atque abiete crispa./ o pater, o patria, o Priami domus,/saeptum altisono cardine templum./uidi ego te adstante ope barbarica,/tectis caelatis laqueatis,/auro ebore instructam regifice./haec omnia uidi inflammari,/Priamo ui uitam euitari,/Iouis aram sanguine turpari./philosophandum est paucis; nam omnino haud placet./quae caua caeli/ signitenentibus conficis bigis (H.D. Jocelyn ed., The Tragedies of Ennius, the Fragments [Cambridge University Press : Cambridge, 1967] Verse 84).

60. I prefer the term cognitive association to folk etymology. Cognitive association implies a vast network of mental and social conditions that give rise to the connection of foedus and foeditas. See G. Rundblad and D. Kronenfeld, "The inevitability of fok etymology : a case of collective reality and invisible hands," Journal of Pragmatics 35 (2003) 119-138.

61. For the Civil War overtones of Priam's death, see A.M. Bowie, "The Death of Priam," CQ 40 (1990) 470-81. We, furthermore, cannot limit this imagery to Book 2, especially in the context of Aeneas' human sacrifice in Book 11, which S. Farron suggests cannot help but recall the Perusine Altars : S. Farron, “Aeneas' Human Sacrifice," Acta Classica 38 (1985) 21-33. See also M. Owen Lee, Fathers and Sons in Virgil's Aeneid (State University of New York Press : Albany, 1979) 14-16 for a discussion the Perusine altars within the context of proscriptions more generally. See also S.F.Wiltshire, Public and Private in vergil's Aeneid (UMASS Press : Anhorst, 1989) 26-8. Suetonius Aug. 15 : Perusia capta in plurimos animadvertit, orare veniam vel excusare se conantibus una voce occurrens "moriendum esse." scribunt quidam trecento ex deciticiis electos utriusque ordinis ad aram Divo Julio exstructam Idibus Martiis hostiarum more mactatos.

62. See Dyson (2001) 30-3 on the significance of this mis-sacrifice and her discussion of Macrobius' analysis of this episode. scimus enim hoc ubique servare Vergilium, ut rebus, quibus denegaturus est exitum, det etiam infirma principia. sic in Thracia civitatem condens Aeneas, quam mox fuerat relicturus, contra morem Iovi de tauro sacrificavit, adeo ut hinc putetur subsecutum esse prodigium. 63. forte fuit iuxta tumulus, quo cornea summo/virgulta et densis hastilibus horrida myrtus./ accessi viridemque ab humo convellere silvam/ conatus, ramis tegerem ut frondentibus aras/ nam quae prima solo ruptis radicibus arbos/ vellitur, huic atro liquuntur sanguine guttae/ et terram tabo maculant. mihi frigidus horror/ membra quatit gelidusque coit formidine sanguis./ rursus et alterius lentum convellere vimen/ insequor et causas penitus temptare latentis:/ alter et alterius sequitur de cortice sanguis./ multa movens animo Nymphis venerabar agrestis/ gradivumque patrem, Geticis qui praesidet arvis,/ rite 
secundarent visus omenque levarent./ tertia sed postquam maiore hastilia nisu/ adgredior genibusque adversae obluctor harenae,/ (eloquar an sileam ?) gemitus lacrimabilis imo/ auditur tumulo et vox reddita fertur ad auris. (3.22-40)

64. This episode shares much with 6.180ff in which Italian antiqua silva is cut down for Misenus' burial. The first interaction with Italian landscape is a repetition of his actions upon Europe. See Dyson (2001) for a discussion of the Trojan inclination to violate Italian landscape.

65. It is notable that the death of Orontes occurs upon Arae that acted as fines between Carthage and Italy, which suggests system related to the Polydorus episode; Aeneas crosses the fines between Asia and Europe and engages with the theme of desecrated altars.

66. Dyson (2001) adds a number of similar ritualistic mistakes made by Aeneas.

67. Ennius' formation of landscapes - as for example in the fragment Europam Libyamque rapax ubi dividit unda (9.4) in his description of the Rocks of Gibraltar - is clearly operational. Gallus is also important: uno tellures dividit amne duas,/ Asiam enim ab Europa separat. See E. Courtney, The Fragmentary Latin Poets (Oxford University Press : Oxford, 2003) 263. Gallus also employs elision in an iconic fashion in this fragment.

68. "I sing of arms and of a man : his fate had made him fugitive; he was the first to journey from the coasts of Troy as far as Italy and the Lavinian shores. Across the lands and waters he was battered beneath the violence of High Ones, for the savage Juno's unforgetting anger ; and many sufferings were his in war - until he brought a city into being and carried in his gods to Latium ; from this have come the Latin race, the lords of Alba, and the ramparts of high Rome."

69. "Then a Trojan Caesar shall rise out of that splendid line. His empire's boundary shall be the Ocean ; the only border to his fame, th e stars."

70. See O'Hara (1990) 155-63 ; E. Kraggerud, "Which Julius Caesar? Symbolae Osloenses 67 (1992) 103-12 ; J. O’Hara, “Temporal distortions, 'fatal' ambiguity, and Julius Caesar at Aeneid 1.286-96," Symbolae Osloenses 69 (1994) 72-82 and E. Kraggerud, "Caesar versus Caesar again: a Reply," Symbolae Osloenses 69 (1994) 83-93. This is not the place to rehearse whether Julius Caesar or Augustus is meant in these lines, but I think it is essential to factor Ovid's Metamorphoses 15.745-842, a moment of prophecy clearly modeled on the conversation of Venus and Jupiter in Aeneid 1. I am currently working on this material, but my initial feelings are that Vergil is referring to Julius Caesar alone or a mixture of Caesar and Augustus. Ovid's reception of the prophecy suggests both possibilities.

71. "The cries of men are high, the trumpets clang."

72. "Commonly states are overturned at the blast of a trumpet just as Tullus Hostilius ordered Alba be destroyed."

73. "But deep within, confusion takes the palace, anguish and sad commotion; and vaulted walls echo with the wail and woe of women, lament that beats against the golden stars. Across the huge apartments in their terror the matrons wander, clutching the doors, embracing them, imprinting kisses."

74. "But the interior house : the passage has been translated from the sack of Alba."

75. "Servius' statements on the two Virgilian passages clearly refer to the same source, which can only be Ennius' account of the destruction of Alba Longa." (Skutch [1985] 179). See A.M. Bowie (1990) n25 and especially Andreola Rossi, Contexts of War: Manipulation of Genre in Virgilian Battle Narrative (University of Michigan Press : Ann Arbor, 2004) 27-47.

76. See Hardie (1992) 59-61.

77. "More : Romulus, a son of Mars. He will join Numitor, his grandfather, on earth when Ilia, his mother, gives him birth out of the bloodline of Assaracus. You see the double plumes upon his crest : his parent Mars already marks him out with his own emblem for the upper world. My son, it is beneath his auspices that famous Rome will make her boundaries as broad as the earth itself, will make her spirit the equal of Olympus, and enclose her seven hills within a single wall, rejoicing in her race of men: just as the Berecynthian mother, tower-crowned, when, through 
the Phrygian cities, she rides on her chariot, glad her sons are gods, embraces a hundred sons of sons, and every one a heaven-dweller with his home on high."

78. On Cybele in Augustan Rome both as a symbol and topographically important entity, see R.M. Wilhelm, “Cybele : Great Mother of Augustan Order," Vergilius 34 (1988) 77-101. To quote Wilhelm (80), "the transformation has been achieved throughout the poet's imaginative linking of the historical coming of Cybele to Rome with the legendary journey of Aeneas to Italy. Both Cybele and Aeneas move civilization westward..."

79. See Wilhelm (1988) 83-4, 92-3. Wilhelm nicely illustrates the parallel between Cybele and Rome in the passage in question (92): "both have offspring...both have walls...both have an empire. In this simile Vergil has inextricably linked the life and fortunes of Cybele and Rome by a comparison that focuses on their qualities as creators and rulers."

80. For a similar point made about references of landscapes in Vergilian similes, see Francis Cairns, Vergil's Augustan Epic (Cambridge University Press : Cambridge, 1989) 113-4. This parallel strikes at the heart of what a poet considered to be the essence of "Rome."

81. "Then we are driven by divine commands and signs to sail in search of fields of exile in distant and deserted lands. We build a fleet beneath Antandros, in the foothills of Phrygian Ida, knowing not where fate will carry us or where we are to settle."

82. "Out in the middle of the sea lies Crete, the island of great Jupiter. There is Mount Ida, cradle of our people. The Cretans have a hundred splendid cities, the richest realms. If I remember what I have heard, our greatest father, Teucer, sailed out from Crete to Rhoetean coasts and chose a place fit for his kingdom. Ilium, the towers of Pergamus were not yet built. Men lived deep in the valleys. And from Crete the Mother Goddess came to Cybele, as did the Corybantes' brazen cymbals within the grove of Ida; and from Crete she brought the reverential silence of her mysteries ; the team harnessed lions that draw her chariot-a Cretan custom."

83. "As I advance, I see little Troy, a Pergamus that mimes the great one, and a dried-up stream that takes its name from Xanthus. I embrace the portals of the Scaean gates. My Trojans also enjoy the kindly city where the king has welcomed them to spacious porches."

84. "Here you can see the image of new Xanthus and of the Troy your hands have built beneath more kindly auspices, I hope - a city less open to the Greeks than was old Troy. If ever I shall enter on the Tiber and on the lands that lie along the Tiber and see the ramparts given to my race, then we, in time to come, shall build one Troy in spirit from our sister cities in Epirus and Hesperia and from our kindred peoples - those who share one founder in Dardanus and share one destiny. May this become the care of all our sons."

85. On the interpretation of Buthrotum (among other landscapes) as the negative pull of the past, see M. Bettini, "Ghosts of Exile : Doubles and Nostalgia in Virgil's parva Troia (Aeneid 3.294ff)," ClAnt 16 (1997) 8-33 ; Wiltshire (1989) 73-8 ; D. Quint, "Repetition and Ideology in the Aeneid," MD 24 (1991) 9-54; Hardie (1993) 16-17. These arguments are only true from the microcosmic perspective of Aeneas as story teller, not from the macrocosmic perspective that is referred to by the Penates, Helenus, and later by Anchises himself in Book 6 and the shield in Book 8. In the Aeneid the past is the future; time has collapsed. The true negative valence of Buthrotum has more to do with the violated landscapes based on ruptured foedera between Europe and Asia than it does on some desire to leave the past behind for the fulfillment of the future. This idea is not in the text, but is rather an interpretation of episodes that have negative valence through Aeneas' eyes. In fact, I read the description of Buthrotum's landscape as an allusion to a skene. Aeneas literally finds himself walking onto a tragic stage to witness Andromache's tragic lament. For a similar point, see Syed (2005) 104-6.

86. On Buthrotum the colony, see Hans Peter Stahl, "Political Stop-overs...from Battling Harpies to the Battle of Actium : Aeneid 3.326-93," Vergil's Aeneid: Augustan Epic and Political Context, ed. Stahl (Duckworth Press : London, 1998) 45-6. 
87. ergo hoc dicit : quoniam et ab uno originem ducimus et iisdem casibus subiacuimus, Troiam utramque, id est quam et tu fecisti et ego facturus sum, iungamus et faciamus unam, sed 'animis', hoc est foedere et adfectione, quoniam re vera eas natura non sinit iungi (ad Aen. 3.501).

88. "When suddenly a tattered stranger, gaunt with final hunger, staggers from the woods and stretches pleading hands toward shore. We turn to look at him : his filth is ghastly - his beard is tangled and his clothing hooked by thorns ; and yet he is Greek."

89. "I am of Ithaca and sailed from Troy, a comrade of unfortunate Ulysses ; my name is Achaemenides, the son of Adamastus, a poor father - would my lot had never changed."

90. See A.G. McKay, “The Achaemenides Episode : Vergil, Aeneid III. 588-691," Vergilius 12 (1966) 31-8 and M. Paschalis, Virgil's Aeneid: Semantic Relations and Proper Names (Clarendon Press: Oxford, 1997) 140.

91. In passing, G.K.Galinsky in "Aeneid V and the Aeneid," AJP 89 (1968) 160 says as much: "(W)ithout any questions, and before he has yet told his story, he is accepted by Anchises, who all but concludes a treaty with him."

92. "Troy (unholy thing!), the common sepulcher of Eurasia, Troy, the repulsive ruins of men and all heroic deeds."

93. To quote Andrew Erskine, Troy Between Greece and Rome (Oxford University Press : Oxford, 2003). "Many of these visitors [Xerxes, Alexander, Antiochos, Mindaros...] to the sanctuary of Athena Ilias were themselves making the crossing between Europe and Asia, and this may have had some bearing on their visit. This was the last or first major sanctuary in Asia, depending on the direction of travel. An army making the crossing of the Hellespont into Europe, or venturing into the new land of Asia, may have felt more comfortable after a sacrifice to Athena. The visit and the sacrifice could have acted as a form of liminal ritual, marking the transition from one continent to another. The border status of the sanctuary was emphasized still further by a panorama that encompassed both Asia and Europe ; anyone standing there could look across the plane of Troy and see the Chersonese stretched out on the far side of the Hellespont. Alexander appears to have treated the crossing as especially significant; he is said to have sacrificed to Athena and other deities, both on his departure from the European shore and then again on his arrival at the Asian side. Because of its position on the threshold between Europe and Asia, Ilion/ Troy may seem in retrospect to symbolize conflict between East and West. This, however, was probably not the intention of the protagonists."

94. See Wiltshire (1989) 92. Furthermore, it is notable that in the myth of Dido handed down by Timaeus and Justin, in which Dido commits suicide on a pyre in order to preserve her chastity for her dead husband, a Libyan is to marry her (see Niall Rudd, Lines of Enquiry [Cambridge University Press: Cambridge, 1976] 48). Vergil inserts Aeneas into the place of the Libyan king. The geographical realities embodied in Aeneas' journey imply that Aeneas is on the verge of becoming a Libyan, a role he partially fulfills. It is this mythological variation that may help explain the crux of her premature death; tradition offered another narrative that she chose not to fulfill.

95. EVROPA ATQVE ASIA PVLSVS aut orbem in tres partes divisit et absolutum est, quia in Africa positus, quae orbis pars tertia est : aut si Europam tantum et Asiam intellegimus, ut Africa in Europa sit, invidiose locutus est, ut supra Venus "cunctus ob Italiam terrarum clauditur orbis", quasi cum indignatione dicat, per Troiam Asia careo, per Italiam Europa (ad Aen. 1.385).

96. "The double offspring of Latona : as if he were saying, each gender of the offspring of Latona or progeny. In addition, he rightly invokes two gods in the foedera, because two peoples are about to come together into one. Also he rightly invokes Janus, because he himself is present at the making of foedera : for after Romulus and Titus Tatius came into foedera, a statue of a double face was made for Janus as through in the image of the two populations."

97. Servius comments are suggestive to say the least. It is notable that along with Janus' duplex frons we can add the point that Apollo and Diana are twins, both double yet singular. 
98. alii dicunt Tatium et Romulum facto foedere hoc templum aedificasse, unde et Ianus ipse duas facies habet, quasi ut ostendat duorum regum coitionem. [vel quod ad bellum itiuri debent de pace cogitare.] est alia melior ratio, quod ad proelium ituri optent reversionem (ad Aen. 1.291).

99. In book 4 Venus rephrases Juno's statement (4.99-104), quin potius pacem aeternam pactosque hymenaeos/ exercemus ?....communem hunc ergo populum paribus regamus/ auspiciis; liceat Phrygio servire marito/ dotalisque tuae Tyrios permittere dextrae, as sed fatis incerta feror, si Iuppiter unam/ esse velit Tyriis urbem Troiaque profectis,/ miscerive probet populos aut foedera iungi. (4.110-12).

100. illud te, nulla fati quod lege tenetur,/ pro Latio obtestor, pro maiestate tuorum :/ cum iam conubiis pacem felicibus (esto)/ component, cum iam leges et foedera iungent,/ ne uetus indigenas nomen mutare Latinos/ neu Troas fieri iubeas Teucrosque uocari/ aut uocem mutare uiros aut uertere uestem. (12.819-25).

101. Hardie (1993) 27 makes a similar point in regard to sacrifice stating that the whole "sacrificial crisis" begins with Iphigeneia, which is itself an inversion of a foedus matrimonii. Through the lens of foedus we can move the crisis back even further in mythic time. Catullus 64 sets the crisis of foedera at the wedding of Peleus and Thetis.

\section{ABSTRACTS}

The following paper argues that the series of desecrated altars that are found in the Aeneid reflects prior moments of ruptured alliances that have taken place in the epic cycle and Roman history more generally. Vergil has constructed these ruptured alliances along a number of parallel lines that focus on the various means by which the poem constructs ethnic and spatial unification. From the perspective of ethnic amalgamation the infectum foedus of Aeneid 12 raises a number of problems concerning the foundation of Rome and the nature of Roman alliance through time. This problematic alliance that ends the poem, however, moves against the theme of East-West unification in which a central feature of Aeneas' actions is the reunification of Europe, Asia and Africa through a new system of alliance.

\section{INDEX}

Mots-clés: Aeneid, Altars, East-West, Etiology, Foedus, Foundation of Rome, Geopoetics

\section{AUTHOR}

BILL GLADHILL

charles.gladhill@mcgill.ca 